\title{
A new species of the genus Giljarovia Kratochvil, 1959 (Arachnida: Opiliones: Nemastomatidae) from the Crimea
}

\section{Новый вид рода Giljarovia Kratochvíl, 1959 (Arachnida: Opiliones: Nemastomatidae) из Крыма}

\author{
A.N. Tchemeris ${ }^{1} \&$ M.M. Kovblyuk ${ }^{2}$ \\ А.Н. Чемерис ${ }^{1}$, Н.М. Ковблюк ${ }^{2}$

\begin{abstract}
${ }^{1}$ Department of Invertebrate Zoology; Institute of Biology, Ecology, Soil, Agriculture and Forest Sciences; Tomsk State University, Lenin av. 36, Tomsk 634010 Russia. E-mail: opiliones@mail.ru

${ }^{2}$ Department of Zoology, V.I. Vernadsky Taurida National University, Yaltinskaya Str. 4, Simferopol 95007, Crimea, Ukraine. E-mail: kovblyuk@mail.ru

${ }^{1}$ Кафедра зоологии беспозвоночных; Институт биологии, экологий, почвоведения, сельского и лесного хозяйства; Томский государственный университет, проспект Ленина 36, Томск 634010 Россия. E-mail: opiliones@mail.ru

${ }^{2}$ Кафедра зоологии, Таврический национальный университет имени В.И. Вернадского, ул. Ялтинская 4, Симферополь 95007, Крым, Украина. E-mail: kovblyuk@mail.ru
\end{abstract}

KEY WORDS: Opiliones, Giljarovia, new species, Crimea.

КЛЮЧЕВЫЕ СЛОВА: Opiliones, Giljarovia, новый вид, Крым.

ABSTRACT. The paper presents the diagnosis and description of a new harvestman species, Giljarovia crimeana sp.n. ( $\bigcirc^{7}$ ), from the Crimea. The species is figured and its distribution is mapped.

РЕЗЮМЕ. Данная работа представляет собой диагноз и описание нового вида сенокосцев, Giljarovia crimeana sp.n. (ठㅇ), из Крыма. Вид проиллюстрирован и дана карта его распространения.

\section{Introduction}

Up to date, the distribution of the genus Giljarovia is known to have been restricted to the Caucasus and northern Turkey. A new species Giljarovia crimeana sp.n. has been found in the Crimea, hence extending the western limit of generic range. The genus Giljarovia currently consists of nine valid species, all of which were (re)described in detail by Redikortsev [1936], Kharitonov [1946], Kratochvíl [1959], Gruber [1976], Martens [2006]: viz., G. redikorzevi (Charitonov, 1946) (Georgia), G. rossica Kratochvil, 1959 (Russia: Krasnodar Territory), G. stridula (Kratochvil, 1959) (Russia: Krasnodar Territory and Georgia), G. thoracocornuta Martens, 2006 (Russia: Dagestan), G. tenebricosa (Redikorzev, 1936) (Russia: Krasnodar Territory, Abkhazia, Georgia, Azerbaijan and Turkey), G. triangula Martens, 2006 (Russia: Krasnodar Territory and Georgia), G. trianguloides Martens, 2006 (Russia: Krasnodar Territory), G. turcica Gruber, 1976 (Turkey), and G. vestita Martens, 2006 (Russia: Krasnodar Territory and Abkhazia).

The aim of this paper is to describe and diagnose a new species from the Crimea.
The specimens used for this study have been deposited in the Institute for Systematics and Ecology of Animals SD RAS, Novosibirsk, Russia (ISEA; curator - Dr. G.N. Azarkina) and the Zoology Department of the Taurida National University, Crimea, Ukraine (TNU; curator - Dr. M.M. Kovblyuk). Abbreviations used in the text and table: Fm - femur, Pt — patella, $\mathrm{Tb}$ - tibia, Mt - metatarsus, Tr — tarsus. 'Clypeus' is the space between the ocularium and the front margin of the carapace. All measurements are in $\mathrm{mm}$.

\section{Description}

Giljarovia crimeana $\mathbf{s p . n .}$

Figs 1-7; Map 1.

MATERIAL. HOLOTYPE: $1 \sigma^{7}$ (ISEA, SZM 000.833), Ukraine, the Crimea, Simferopol Distr., Orlinoe Gorg of E slope Chatyr-Dag Massif, 27.04-02.12.2000, M.K. PARATYPES: $8 \sigma^{7} \sigma^{7}$ 22 우 (ISEA, SZM 000.834), $20^{7} O^{\top} 2$ 우 (TNU), together with the holotype; $1 \mathrm{O}^{7}$ (ISEA, SZM 000.835), the Crimea, Nikitskaya Yaila (Scrinita), 22.04-4.05.2001, M.K.

DIAGNOSIS. The genus Giljarovia differs from other genera of the Nemastomatidae by the presence of stridulatory apparatus which includes the ocularium armed with modified tubercles and setae and the stridulatory area on palpal femora (Fig. 3). Giljarovia crimeana sp.n. can easily be distinguished from other Giljarovia species by the shape of eye tubercle, the basal segment of male chelicerae, palpal femur and the penis (Figs 1-7). By the penis' structure (Figs 5-7), the new species is closest to G. redikorzevi (Martens, 2006). The ocularium with cuticular papillae situated laterad of the eyes (Fig. 2). The basal segment of chelicera 


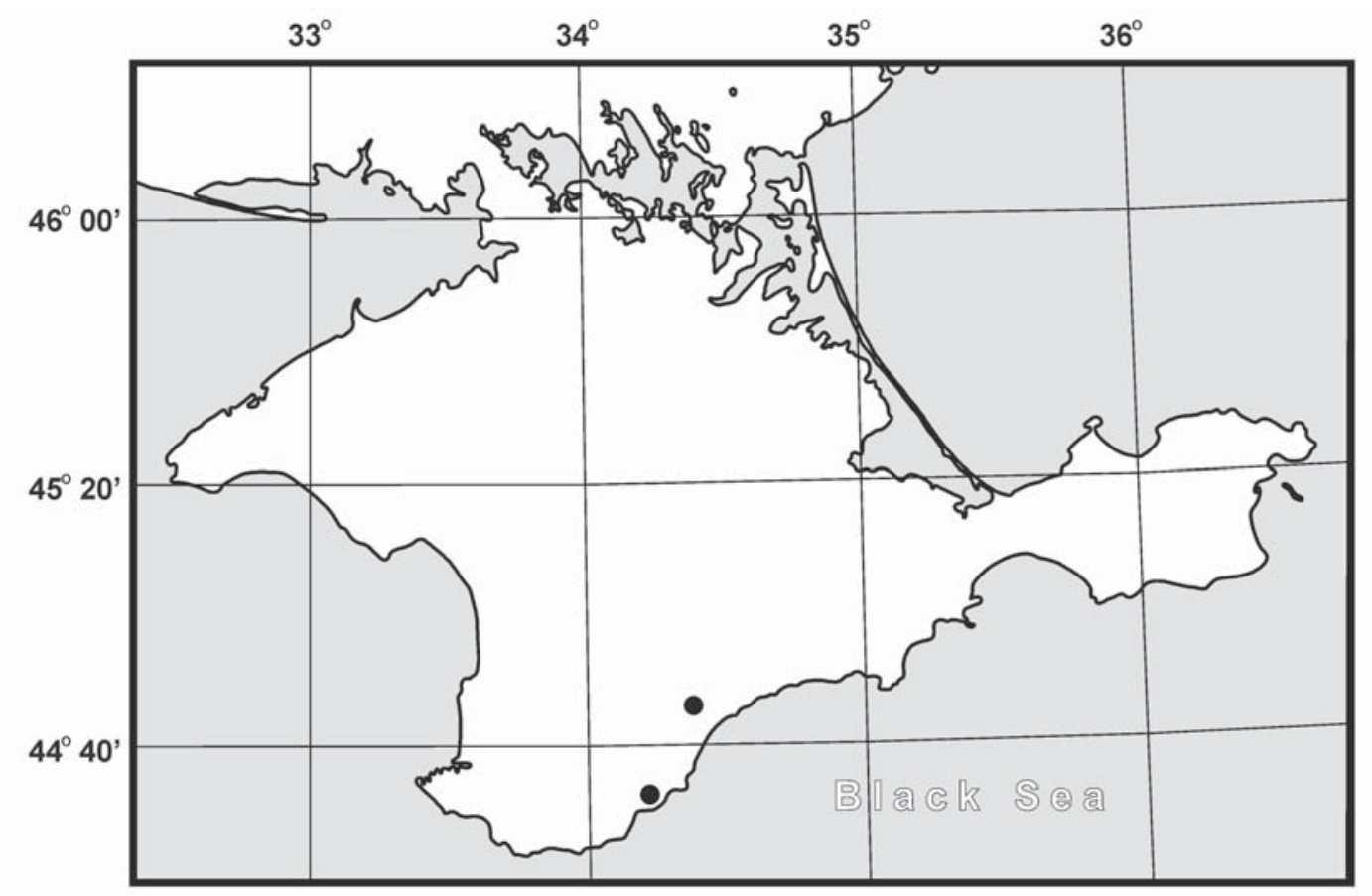

Map 1. Distribution of Giljarovia crimeana sp.n.

Карта 1. Распространение Giljarovia crimeana sp.n.

with the well-developed, obtuse apophysis (Fig. 4). The palpal femur with the elongate stridulatory area (Fig. 3).

DESCRIPTION. MALE. Measurements. Body: length 2.02; width 1.32. Cephalothorax length 0.51 . Eye tubercle width 0.40 . 'Clypeal' length 0.05 . Chelicera: basal segment length 0.63; distal segment length 0.44 ; length of forceps 0.33 . Penis: length 1.48 ; width at base 0.19 . Length of palp and legs:

\begin{tabular}{|l|c|c|c|c|c|c|}
\hline & Fm & Pt & Tb & Mt & Tr & Total \\
\hline Palp & 0.72 & 0.59 & 0.54 & - & 0.35 & 2.2 \\
\hline Legs & & & & & & \\
\hline I & 1.38 & 0.51 & 1.04 & 1.14 & 0.94 & 5.01 \\
\hline II & 2.56 & 0.58 & 2.31 & 2.32 & 1.01 & 8.78 \\
\hline III & 1.51 & 0.52 & 1.19 & 1.27 & 0.92 & 5.41 \\
\hline IV & 2.32 & 0.60 & 1.61 & 1.94 & 1.16 & 7.63 \\
\hline
\end{tabular}

The male body as in Fig. 1: subrectangular with rounded angles. Dorsum is covered throughout with low, blunt tubercles. Body integument papillose. No sharp borders between tergits. Anterior part of the carapace and the eye tubercle covered with tack-like and macelike tubercles, which are considerably bigger than other tubercles. Dorsum with numerous small blunt tubercles situated in groups as follows: on the carapace between chelicerae and legs I; between legs II and III; and on the distal edge of terminal abdominal tergites. Abdominal tergites I-VI with a pair of high, cylindrical tubules inclined posteriorly. Tips of these tubules covered with aciculae. Supracheliceral lamellae (Figs 1-2) big with group mace-like tubercles, are visible from above.
Eye tubercle (Figs 1-2) is very low and spherical, shifted forward to the edge of the carapace, with numerous small blunt mace-like tubercles. There are 11 to 12 cuticular papillae situated laterad of each eye from its middle part towards its anteriour edge (Fig. 2).

Chelicera small (Fig. 4). Basal segment dorsally with a very well developed apophysis (the cheliceral gland). Dorsal surface in front of the apophysis is armed with group from 3-5 small tubercles. This apophysis is equal in length to the basal segment. Distal segment (in lateral view) is enlarged in its medial part. Chelicera is covered with setae.

Palps (Fig. 3) short, covered with mace-like setae and hairs. Femur somewhat curved, with elongate stridulatory area from its middle part to the distal end. Tarsus relatively long, more than a half of the tibia. Tarsal claw are absent.

Legs (Fig. 1) relatively long, spindle-shaped, covered with small denticles, setae and hairs. Femora, patella and tibia I and III swollen. Femora with pseudosegments as follows: I -0 , II $-4-5$, III $-1-2$, IV - 3. Coxa with a row of mace-like tubercles on each side. Penis as in Figs 5-6. Corpus thin with abruptly widened base. Glans (Fig. 7) somewhat swollen, gradually merging into stylus. Corpus on the top with lateral depressions which are covered by membranes. Glans covered with scattered spicules.

Coloration. Body and limbs ochre, with scattered brown and dark-brown spots. Dorsum behind the ocularium with a wide black-brown stripe. The pattern 


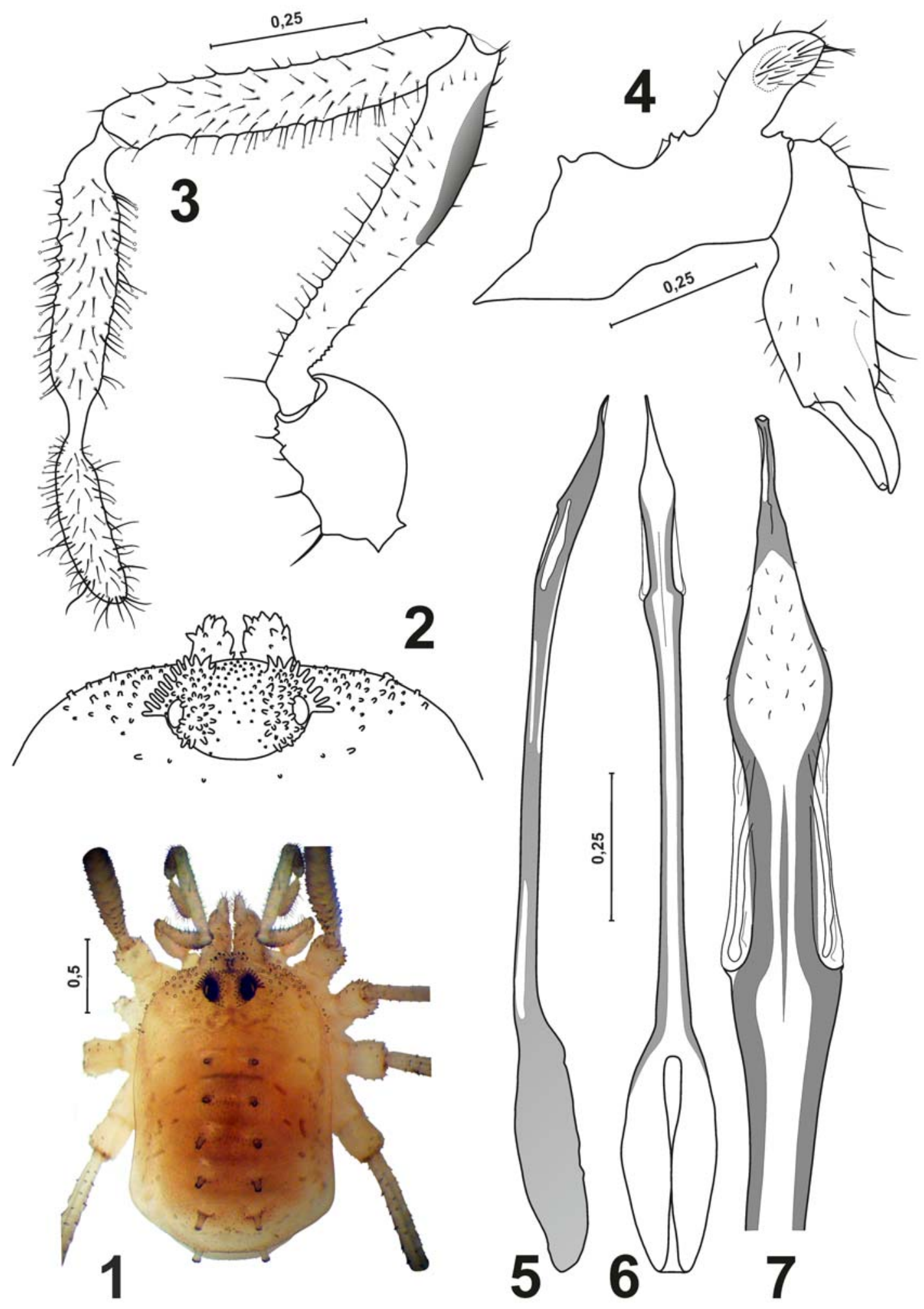

Figs 1-7. Giljarovia crimeana sp.n.: 1 - paratype, male body, dorsally; 2 - ocularium and front edge of carapace dorsally; 3 - male palp, ectally; 4 - male chelicerae, mesally; 5 - penis, laterally; 6 - penis, dorsally; 7 - glans, dorsally.

Рис. 1-7. Giljarovia crimeana sp.n.: 1 - паратип, тело самца, вид сверху; 2 - глазной бугор и передняя часть карапакса, вид сверху; 3 - пальпа самца, вид снаружи; 4 - хелицера самца, вид изнутри; 5 - пенис, вид сбоку; 6 - пенис, вид сверху; 7 головка пениса, вид сверху. 


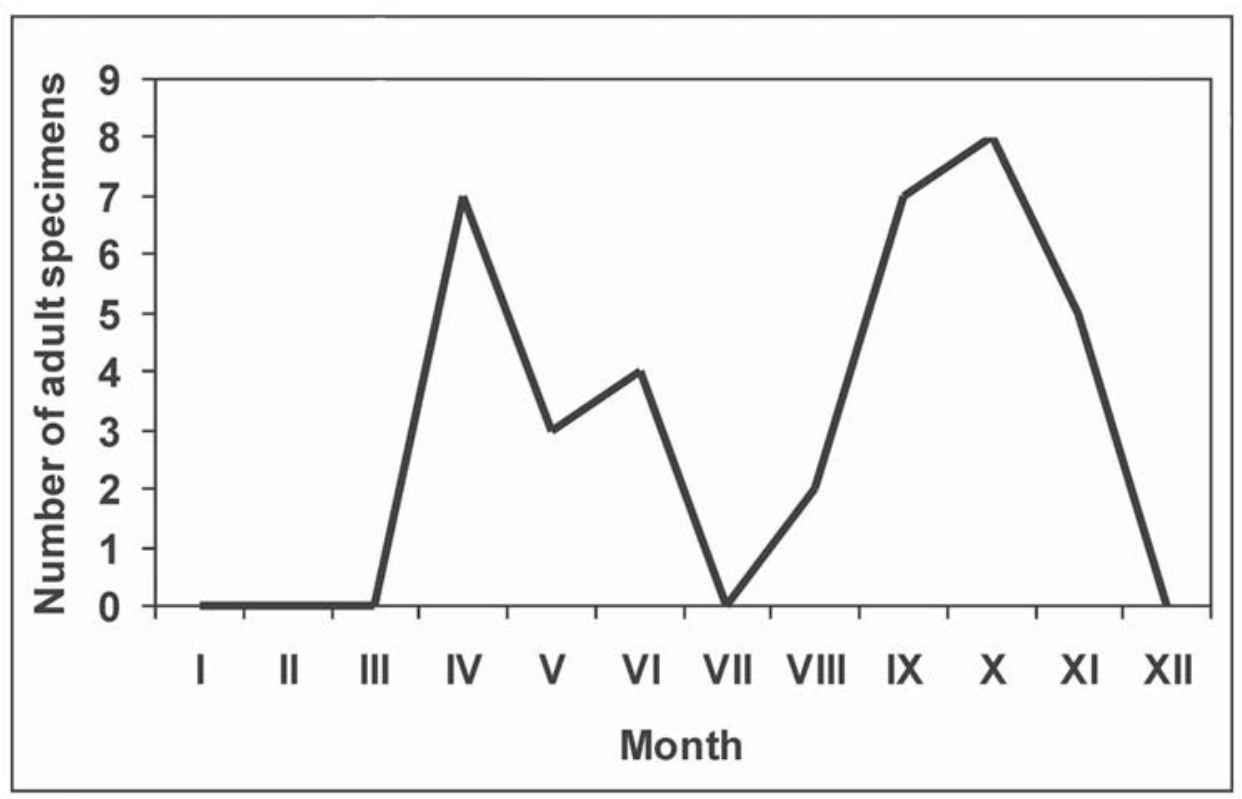

Fig. 8. Phenology of Giljarovia crimeana sp.n. in the Crimea, based on the collected specimens.

Рис. 8. Фенология Giljarovia crimeana sp.n. в Крыму по материалам коллекции.

around the eye black-brown, cuticular papillae dark brown.

FEMALE. Measurements. Body: length 2.96; width 1.72. Cephalothorax length 0.60. Eye tubercle width 0.44. 'Clypeal' length 0.01. Chelicera: basal segment length 1.69; distal segment length 0.42 ; length of forceps 0.27 . Length of palp and legs:

\begin{tabular}{|l|c|c|c|c|c|c|}
\hline & Fm & Pt & Tb & Mt & Tr & Total \\
\hline Palp & 0.78 & 0.62 & 0.53 & & 0.26 & 2.19 \\
\hline Legs & & & & & & \\
\hline I & 1.22 & 0.51 & 1.00 & 1.06 & 0.82 & 4.61 \\
\hline II & 2.14 & 0.58 & 2.02 & 2.07 & 1.67 & 8.48 \\
\hline III & 1.49 & 0.42 & 1.06 & 1.14 & 0.83 & 4.94 \\
\hline IV & 2.11 & 0.58 & 1.53 & 1.88 & 1.17 & 7.27 \\
\hline
\end{tabular}

General appearance as in the male, but the female has a longer body and lacks the apophysis and tubercles on the basal segment of the chelicerae. Femora with pseudosegments as follows: I -0, II $-5-6$, III $1, \mathrm{IV}-3$.

ETYMOLOGY. The name of the species originates from its type locality, the Crimea (Ukraine).

DISTRIBUTION. Ukraine: the mountainous part of the Crimea [present data].

HABITAT. Traditionally, seven natural (landscape, altitudinal, physic-geographical) zones are described from the Crimean peninsula: 1) the semi-desert steppes and saline lands; 2) the genuine steppes; 3) the submontane forest-steppes; 4) the forests of the northern slope; 5) the mountain meadows and yaila steppes; 6) the forests of the southern slope; 7) the sub-Mediterranean vegetation of the southern coast. All of them have been surveyed with regards to the opilionid fauna. The new species was collected from the zone of mountain meadows and yaila steppes (5), at about 900-1200 m a.s.l., in a karst subsidence having the forests of Pinus,
Fagus, Populus, Acer and Cornus mas. It is likely that this species occurs in karst cavities, in the leaf litter.

PHENOLOGY. All the studied specimens were collected by pitfall traps, which were regularly checked for over a year. Thus, it was possible to present the seasonal dynamics of adult activity: $\sigma^{7}+-$ IV-VI, VIII-XI (see Fig. 8). The new species clearly shows two peaks of activity: in April and in October, which may indicate the occurrence of two generations per year in this species.

ACKNOWLEDGMENTS. We are obliged to Dr D.V. Logunov (Manchester, UK) for improving the English of the early draft. This work of M.K. was supported in part by the Karadagh Nature Reserve.

\section{References}

Gruber J. 1976. Ergebnisse zoologischer Sammelreisen in der Türkei: Zwei neue Nemastomatidenarten mit Stridulationsorganen, nebst Anmerkungen zur systematischen Gliederung der Familie (Opiliones, Arachnida) // Annalen des Naturhistorischen Museums in Wien. Bd.80. S.781-801.

Martens J. 2006. Weberknechte aus dem Kaukasus (Arachnida, Opiliones, Nemastomatidae) // Senkenbergiana Biologica. Bd.86. H.2. S.145-210.

Kharitonov D.E. 1946 [Arachnoidea from Sataple cave (Kutaisi)] // Doklady AN GruzSSR. Vol.7 (for 1945). P.145-147 [in Russian].

Kratochvíl J. 1959. [On a new subfamily of opilionids (Giljaroviinae, Nemastomatidae) with a key to the identification of genera of Nemastomatidae] // Zoologicheskiy Zhurnal. Vol.38. P.13441352 [in Russian, with German summary].

Redikortsev V.V. 1936 [Beiträge zur Opilioniden-Fauna von U.S.S.R.] // Trudy Zoologiceskogo Instituta AN SSSR. Vol.3. P.33-57 [in Russian and German].

Responsible editor D.V. Logunov 